University of Nebraska - Lincoln

DigitalCommons@University of Nebraska - Lincoln

Agronomy \& Horticulture -- Faculty Publications

Agronomy and Horticulture Department

$9-1932$

Root System of Quercus macrocarpa in Relation to the Invasion of Prairie

J. E. Weaver

University of Nebraska-Lincoln

Joseph Cramer

Follow this and additional works at: https://digitalcommons.unl.edu/agronomyfacpub

Part of the Plant Sciences Commons

Weaver, J. E. and Cramer, Joseph, "Root System of Quercus macrocarpa in Relation to the Invasion of Prairie" (1932). Agronomy \& Horticulture -- Faculty Publications. 450.

https://digitalcommons.unl.edu/agronomyfacpub/450

This Article is brought to you for free and open access by the Agronomy and Horticulture Department at DigitalCommons@University of Nebraska - Lincoln. It has been accepted for inclusion in Agronomy \& Horticulture -Faculty Publications by an authorized administrator of DigitalCommons@University of Nebraska - Lincoln. 


\title{
ROOT SYSTEM OF QUERCUS MACROCARPA IN RELATION TO THE INVASION OF PRAIRIE
}

\author{
J. E. Weaver and Joseph KRamer
}

(WITH TEN FIGURES)

\section{Introduction}

Invasion of trees into grassland is primarily a phenomenon of plant competition. It involves the relation of the invaded and the invader to light and other atmospheric factors of the habitat, both physical and biotic. But perhaps even to a greater degree the edaphic factors, and especially water in dry climates, are concerned. Consequently to understand the reasons for plant distribution and the changes resulting from natural successions, a knowledge of the parts of the plants underground and of the interrelations of the root systems is of fundamental importance.

The great tension zone or ecotone between the deciduous forest formation of the eastern United States and the grassland formation that centers west of the Missouri River occurs, in part, in eastern Nebraska. It offers a convenient and fascinating field for the study of the age-long struggle between grassland and woodland for possession of the territory bordering the Missouri River. Here the many factors of soil and climate, controlled by limited humidity above ground and scarcity of water beneath, offer conditions under which it is just possible for sturdy pioneer trees to ecize but never to develop to the stature of their kind under more congenial conditions of growth. Against their invasion Andropogon and other grasses compete most severely and in the main successfully.

Much work has been done on the root habits of the prairie vegetation; some studies have been made of the underground parts of the bordering chaparral; but little is known of the root relations of deciduous forest trees, except in the seedling stage of growth. To understand the problem of the invasion of trees into grassland, some knowledge of the soil and climate and of the character of the grassland is indispensable. 


\section{SOILS AND CLIMATE}

The soils of eastern Nebraska, where these studies were made, are rather diverse in character. They include the mellow loess soils immediately bordering the Missouri River, and also those of the drift hills and of the alluvial plains and terraces. Whether the Wabash silt loam of the valleys or the Carrington silt loam of the uplands or other soil types are concerned, they all agree in having great depth and a constantly moist subsoil. After studying the root habits of different types of plants in a wide range of habitats, it has been found that various types of soils may influence the environment in a very similar manner. The ecological significance of various soil types is related to their ability to supply water and the necessary nutrients to the vegetation. The cover of grassland, for example, is very similar in species, structure, and manner of growth throughout much of eastern Nebraska. The various types of prairie that do occur are clearly related to water content of soil, but only obscurely, if at all, to soil type (cf. I8).

In general, the soils are deep, fertile, fine-textured loams of high water-holding capacity and are circumneutral in reaction. They readily absorb water and the subsoil is always moist to great depths. The mean annual precipitation varies from 28 to 33 inches, nearly 80 per cent of it falling during the growing season. Periods of drought of I5-30 days' duration are likely to occur at any time, and especially after midsummer.

Studies extending over a period of 12 years have been pursued at Lincoln, Nebraska, where the mean annual precipitation is 28 inches (30). It has been shown that the available water content in the surface 6 inches of upland soil, which supports a growth of the climax prairie vegetation, was reduced to less than 5 per cent at one or more times nearly every year; but only twice during this period was it reduced to the hygroscopic coefficient. In the second 6-inch level, available water content exceeded 5 per cent three-fourths of the time but was frequently reduced to $2-3$ per cent. At no time, however, was the water available for plant growth entirely exhausted. In the second, third, and fourth foot, where water content was less variable, the available supply usually ranged between 5 and I 5 per 
cent. The maximum was $2 \mathrm{I}$ per cent and a few times the minimum fell to $I-3$ per cent. In lowland prairie the available water content was $3^{- \text {Io }}$ per cent greater in the surface foot and $5^{- \text {II }}$ per cent in excess of that of the upland in the deeper soil.

Under an increasing rainfall eastward (maximum 33 inches in Nebraska), the water content has been found to be rather consistently somewhat higher. This is indicated by the greater abundance and wider distribution of the less xeric prairie species, by the growth of chaparral, and by the appearance of the forest. Intermittent determinations of the water content, often during root examinations where excavations 8-22 feet in depth were made, have shown that the soil below 4 feet is also rather moist. It is upon the direct supply of water from rainfall that invading upland forest trees depend. They are not furnished with moisture from the water table (7).

Not only is the soil relatively dry when compared with that of the main body of the deciduous forest, but also the air has a great power of desiccation. It is a region with much sunshine, high summer temperatures, high evaporation, much wind movement, and relatively low humidity. During March, April, and May there is approximately 60 per cent sunshine; but June, July, and August have 72 per cent or more. Average day air temperatures sometimes reach $90^{\circ} \mathrm{F}$., and maximum air temperatures sometimes reach or exceed $100^{\circ} \mathrm{F}$. More usually the average day temperatures are from $75^{\circ}$ to $85^{\circ}$. The average night temperatures are $10^{\circ}$ or more lower. Evaporation rarely falls below an average weekly loss of to cc. per day and is more usually $20-30 \mathrm{cc}$. During periods of drought, however, it sometimes reaches $40-55 \mathrm{cc}$. Wind movement is rather constant and often high, and is an important factor in promoting water loss. The average day humidity ranges between 50 and 80 per cent during years of greater rainfall but falls frequently to $40-50$ per cent during drier years. The average night humidity is frequently 20 per cent higher. These combined conditions promote a high rate of transpiration and great evaporation from the surface soil. These water losses have been found to average nearly a pound of water per square foot of soil surface per day (28). Thus water content in the first 6-inch layer of soil varies widely and rapidly, often Io per cent or more during a single week. 
THE PRAIRIE

The grasslands, before they were broken, formed an almost uninterrupted cover over most of the area. The dominant species of lowlands is the big bluestem (Andropogon furcatus). This grass is distinctly a sod former, owing to extensive propagation by rhizomes. It grows throughout the entire warm season and forms dense stands 6 to Io feet in height. Indian grass (Andropogon nutans), tall panic grass (Panicum virgatum), and nodding wild rye (Elymus canadensis) are the principal grasses accompanying it. They have rather similar habits and stature. Near the forest border, owing to a greater supply of water, this type of prairie extends far up the slopes and often entirely over the hills. The grasses are intermixed with many legumes, composites, and other forbs, which are, however, always of minor importance. Although only I $2-20$ per cent of the soil surface is actually covered, no large spaces are left unoccupied; and the foliage is so dense that the apparent cover is nearly always 90 to Ioo per cent (27).

The soil is thoroughly occupied by roots. The really magnificent network of the roots of the grasses completely threads the soil to depths varying from 5 to Io feet. In the surface especially they form a dense sod. Most of the forbs absorb at even greater depths than the grasses; many extend their root systems to I $2-16$ feet and some much deeper. The soil is so thoroughly occupied that invasion, even by the roots of trees, seems impossible. The root systems are layered, so that the areas of water control do not too greatly overlap and become too severely competitive.

Smaller areas bordering the forest are held by upland types of grassland. Chief among these is the little bluestem (Andropogon scoparius) type. This species ordinarily forms an interrupted sod, the mats or tufts being so dense that few other plants can invade. Accompanying grasses (A. furcatus, Poa pratensis, etc.) and forbs grow between the mats. Ordinarily only I $2-20$ per cent of the soil surface is covered by the bases of the plants, but the tops spread so widely that the apparent cover is $80-$ Ioo per cent (3I). Although the plants in this type of prairie are not so tall $\left(0.5^{-4}\right.$ feet) nor the vegetation so dense, yet under ground the space is even more thoroughly occupied. The roots of the grasses are finer and have more 
and longer branches, undoubtedly an adaptation to secure sufficient water from these drier uplands. The general level of the mat of grass roots scarcely exceeds $3-5$ feet, but the deeper soil is well filled with the more extensive roots of numerous accompanying forbs. Many of these are regularly 8-I 2 feet deep and some 16 to over 22 feet.

It is with such dense, deeply rooted vegetation that an invading species must compete. The invader must not only endure the shade of the grasses, which is often considerable and not infrequently fatal, but also must wrest from the soil the rather scant water supplies in competition with a wonderfully developed system of absorbing organs. Frequently such invasion is accomplished by shrubs that fringe the forest, and the territory thus gained is later appropriated by the trees.

\section{INVASION BY CHAPARRAL}

The more protected ravines of the prairie frequently contain one or more species of shrubs that constitute the marginal chaparral of the deciduous forest. With an increase of soil moisture as the forest margin is approached, these shrubby plants not only become greater in number of species and stature but also they migrate up the slopes and over the hilltops and often form a more or less continuous, narrow border a few rods to a few miles in width between grassland and forest (3). Of the numerous species concerned, the three most important are smooth sumac (Rhus glabra), coralberry (Symphoricarpos symphoricarpos), and hazelnut (Corylus americana). Where they are found in common their zonal distribution on slopes shows Rhus to be the most xeric. It is also found farthest from the forest margins and is not very tolerant of shade. Corylus is the most shadeenduring and does not pioneer far ahead of the forest border. Symphoricarpos is somewhat intermediate.

Rhus glabra spreads into grassland by means of very long underground stems, some of which give rise to new shoots 20 to 30 feet from the parent plant. These stems extend outward from the established area usually at depths of only $3^{-12}$ inches. The main roots from old plants extend downward and outward under the grass sod, some finally reaching depths of $7-8$ feet; but throughout their course they give rise to numerous branches. Many of these, and sometimes the main roots as well, turn obliquely upward and thread the sur- 
face soil with a vast network of absorbing laterals (25). Thus the roots compete severely with those of the grasses for the water which supplies a growing system of shoots. These shoots ultimately coalesce into a closed canopy above the grasses, which finally disappear as a result of shading.

Symphoricarpos symphoricarpos grows in clumps to a height of only 2 to 5 feet. Its shade is frequently so dense as to exclude even the very tolerant Poa pratensis, although this and other grasses may occur between the clumps. The root system is usually only 4-6 feet deep, but lack of linear extent is amply compensated by a well developed absorbing surface. The finest rooted grasses alone excel this species in its thorough occupancy of the soil. The area is extended under ground by efficient rhizomes, and above ground runners play a similar but less effective part. The chief means of invasion are shading and establishment of new plants among the invaders by vegetative propagation.

Corylus americana spreads by means of large, woody, underground parts 4-6 inches below the surface of the soil. These give rise to new shoots I to 2 feet beyond the parent plant. An abundance of new roots also arise from the rhizomes. Some of the smaller roots run vertically toward the surface and branch profusely into very fine ultimate laterals, for Corylus, like the preceding shrubs, is a strong competitor of the grasses for the water in the surface soil. Competition for water is keen at all levels to which the grasses penetrate, the roots of Corylus usually extending deeper than those of the grasses. Above ground the grasses disappear in the shade of the overhanging branches which lean outward I to 3 feet. In this marginal territory, the prairie grasses first cease to form seed and then die. Often new shoots of Corylus spring from rhizomes that have extended well into the marginal area. The additional shade cast by these increases the handicap.

The intrusion of the shrubs is by mass invasion. As new plants invade by rhizomes, a mulch of leaves is held among the stems. This follows closely upon the periphery of the advancing shrubs and is very effective in further handicapping the growth of the already weakened plants of the prairie. An advance of only 2 or 3 feet may 
require 3 to 5 years, so delicate is the balance between invaded and invader (8).

The occupation of grassland by forest is often attained only as a result of changes in the habitat brought about by the shrubs. But in many places the bur oak is invading the grassland without the aid of the shrubs. To understand the phenomenon of successful invasion of chaparral or grassland by trees, a knowledge of the root systems of trees is of primary importance.

\section{ROOT SYSTEMS OF TREES}

Very little work has been done in America on the root systems of mature trees. In Europe this study has been pursued rather vigorously, especially in Germany, Finland, Russia, and adjacent countries. Most of these studies have centered about coniferous species and much less attention has been given to the trees of deciduous forest. Some of these findings will be discussed later, but a complete bibliography need not be given since such studies have only recently been well summarized. An excellent résumé of the work of European investigators is given by BÜSGEN and MÜNCH (6), and a much more elaborate one by LAITAKARI (I4), in his monograph on the root system of Pinus sylvestris. He reviews the European investigations from the time of HARTIG (I85I) and also includes some American work. More recently Stevens (22) has given a historical review of both European and American investigations on root growth and root competition of trees.

It is gratifying to note that American foresters are beginning to realize that the major problems of silvicultural practice are intimately related to root growth. Only a beginning has been made, however, and the study of the root systems of trees is at best almost a virgin field in America. The great amount of labor involved in the excavation of even a single mature root system has probably been the principal deterrent factor to such investigations (fig. I).

Some of the best work in the past ten years, the results of which offer immediate application, has been done with the root systems of fruit trees. In some cases the entire soil mass penetrated by the roots was removed in $50 \mathrm{~cm}$. cubes. For each tree excavated over 
60 tons of soil was thus handled. The roots from each cube were weighed and graded. This was supplemented by excavating the larger roots and as much fiber as possible, after careful measurement, and arranging and photographing them in their natural position when all had been removed from the soil (2I).

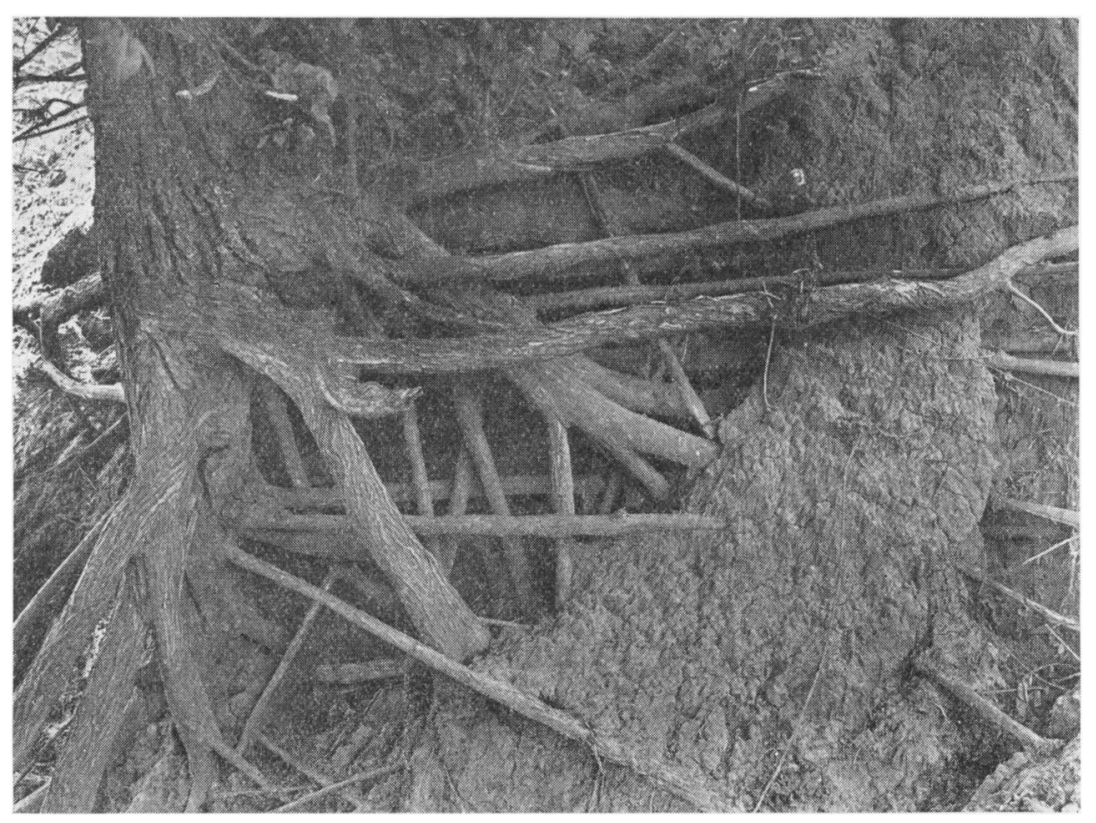

FIG. I.-Portion of root system of Ulmus americana along an eroding ravine; such trees occur on upland soil along the Missouri River and do not necessarily depend upon the roots reaching water table for constant supply of moisture.

The growth of roots of seedlings of five species of deciduous trees has been studied in eastern Nebraska on three classes of sites. The form of the root system appeared to be hereditary with the species and was more or less closely correlated with the water content of the soil in the location naturally occupied by that species (12).

GURSKY (I0) has shown that even related species of mature trees may differ in their root habits, not only as to penetration into the soil but also as to root type. For example, Fraxinus excelsior has the generalized type of root system while $F$. pennsylvanica differs sharply in lacking the vertical taproots. 
Although the root habits of a tree are governed, first of all, by the hereditary growth characters of the species, they are often quite as much the product of environment. Indeed, the impression has been gained by certain investigators that in some cases the root form is an expression of soil environment rather than that of inherent tendencies (24).

The senior writer has found that competition of grasses has a pronounced effect, not only upon the growth of the seedlings but also upon the form of the root system. Three-year-old trees of Gleditsia triacanthos, Acer negundo, Fraxinus lanceolata, and Ulmus americana were examined. The dwarfed plants that had grown in competition with the grasses had a relatively diminutive taproot system with few long branches. Those about which the grasses were kept closely clipped were more extensive and somewhat symmetrical in shape. Where the sod had been removed to a distance of 6 inches on both sides of the trees along another row, the root system was very asymmetrical and $5^{-} 9$ feet deep. The widely spreading branches showed a marked preference for the mulched area, the maximum lateral spread ( $3-7$ feet) always being found in it and not in the sod on either side (8).

According to LunCz (I6), experimental evidence shows that variations in the root system of the same kind of tree are often greater in different soils than are those of different kinds of trees in the same type of soil. He concludes that the tree itself is not in the main responsible for the development of its root habit, but that this is determined by the composition of the soil and subsoil, nutrients, air, water, competition between root systems, etc. It must accommodate itself to conditions occurring during its life.

Other investigations might be cited, but enough has been given to indicate the need of knowledge of the soil and of the general competitive conditions under which the bur oaks to be described have developed.

\section{Investigation}

THE OAK FOREST AND THE SOIL PROFILE

The Carrington silt loam from which the root systems were excavated is a typical prairie soil. It has been occupied by only one or possibly two generations of trees. These have migrated on to the 
uplands from the valleys along streams where they were protected from prairie fires. Most of this migration and invasion of prairie has occurred in the 70 years since the early settlement of eastern $\mathrm{Ne}$ braska and the cessation of prairie fires. Three lines of evidence substantiate this fact. Pioneers are still living who well remember that the trees existed only as marginal forests in sheltered places, largely along streams. There are no very old trees found standing today nor mounds or pits to mark their former abode. Finally, the soil is scarcely modified, except in its very surface, from that of the profile of typical prairie soil.

The bur oak forest where the excavations were made is typical of those of the forest margin in eastern Nebraska (fig. 2). It consisted of a pure open stand. The trees were mostly about 50 to 65 years old, 30-40 feet tall and $12-18$ inches in diameter near the base. They were rather widely spaced (ro-40 feet). The individuals had well developed crowns with large branches and stout, somewhat sparse branchlets. About half of the ground was carpeted with Poa pratensis, the shade and leaf litter elsewhere being too deep for this grass. Corylus americana, Symphoricarpos symphoricarpos, Rhus glabra, and Cornus asperifolia were the characteristic shrubs, although Rhamnus lanceolata, Sambucus canadensis, and Cornus stolonifera also occurred. Owing to utilization of the forest as pasture land, the shrubby growth was only poorly represented.

The mature soil profile is well developed, showing that it has been undisturbed by excessive erosion, except in very recent years. The soil is of glacial origin. There was only a small percentage (about Io) of particles coarser than fine sand, and the fine sand rarely exceeded $\mathrm{r} 5$ per cent. The bulk of the soil at all depths to $\mathrm{I} 2$ feet consisted of about equal proportions of very fine sand, silt, and clay, with the clay fraction preponderating at depths beyond $\mathrm{I} 2$ inches. Horizon $A$, or zone of extraction, from which the carbonates have been leached and much of the clay alluviated, extends to a depth of about I8-20 inches. It has an excellent granular structure and a water-retaining capacity (HILGARD method) of approximately 60 per cent. A thin layer of humus occurred only in the surface inch. Horizon $B$, or zone of concentration, where much clay has accumulated, is about 22 inches thick, reaching a depth of 40 inches. Much of the lime has been leached from this horizon. The shrinking of 
the soil in drying and its cleavage into long perpendicular columns give the soil of this horizon a distinctly columnar structure. At greater depths, in horizon $C$, where neither extraction nor accumulation of materials has occurred as a result of soil-forming processes, the soil has a massive structure. This horizon extends far beyond the depths of the roots of the trees. The carbonate content is high,

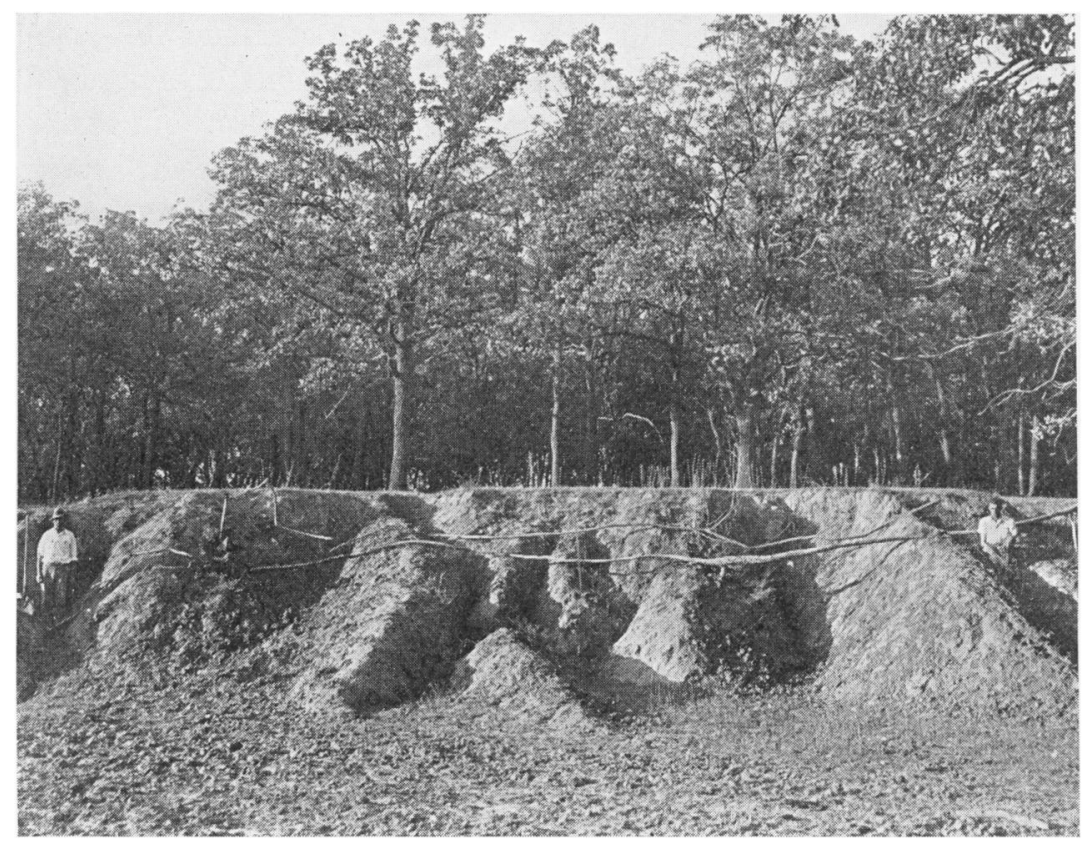

Fig. 2.-Portions of main lateral roots of bur oak 40-55 feet in length. The stand of oaks in background is somewhat denser than where excavations were made.

streaks of chalky material being somewhat in evidence. The soil is friable, more easily penetrated by roots than is the columnar layer above, and prismatic cleavage becomes imperfectly developed. With increasing depth the color likewise changes. The very dark brown of horizon $A$ intergrades into the grayish brown of the deeper one, and this in turn shows a transition to buff in the massive layer.

\section{ROOT SYSTEM OF SEEDLINGS}

In regard to the establishment of the individual tree, it has been shown (23) that the initial root habit is an important and often a 
determining factor in the survival or death of the seedling. The amount of water and nutrients that will be made available to the seedling depends upon the initial root habit, which it seems is in turn dependent upon the species and is not in most cases at once modified by external conditions.

An adaptation of the bur oak to dry sites is shown in its extending the taproot deeply, usually about 9 inches, before unfolding the leaves above ground (I2). Moreover, the root continues to penetrate the soil at a rapid rate and thus avoids succumbing to drought during summer when the surface layers may become dry. The senior writer has traced the development of the seedlings where the acorns were planted among the prairie grasses. A depth of more than 3 feet was attained the first year. More recently HoLCH (I2) has studied the root activities of this species in cultivated soil on a cleared hilltop in eastern Nebraska. At the end of the first growing season a depth of 5 feet and a total lateral spread of 30 inches were attained. By the second autumn it had extended 2 feet deeper and the lateral spread had reached 38 inches. An examination of 3 -yearold seedlings showed that the taproot had reached a depth of 8.5 feet and some of the main laterals had grown so vigorously that the total spread of branches was 5.2 feet. This rapid growth explains the ability of the bur oak to thrive on upper slopes and exposed hilltops in soil so dry that all other native trees fail. A study of its very abundant laterals which clothe the taproot from near the soil surface to the maximum depth of penetration also explains how this species can compete successfully for water with the shrubs and grasses.

The rapid growth of lateral branches, some near the soil surface, during the third year is of interest. In its younger stages this tree has, generally speaking, only feeding roots; later it develops anchorage roots.

\section{EXCAVATION OF MATURE ROOT SYSTEM}

A mature tree 65 years old, 37.5 feet tall and $\mathrm{I}_{4}$ inches in basal diameter, was selected for the initial excavation. A portion of the root system near the trunk was exposed as a result of erosion. This had occurred almost entirely within recent years and after the tree 
was nearly mature. It was the result of close pasturing with both cattle and swine.

The general plan of procedure was first to excavate the taproot and those parts of the laterals that occurred within a radius of $\mathrm{I} 2$ feet from it. Afterward the branches extending beyond this area were traced. This method was followed in order to reduce, so far as possible, the great labor involved in removing a large volume of soil, the original excavation being filled in the process of obtaining the long lateral branches.

Primary laterals.--All of the soil of horizon $A$ was carefully removed from the circular area and most of the major roots exposed to a depth of about 2.5 feet (figs. 3,4 ). Each primary lateral was numbered and measured, and the number, diameter, and direction of growth of its branches were recorded. The branches were then severed from the primary lateral and temporarily left in place. The main root was cut where it branched from the taproot and also at the place where it left the excavated area, or entered the deeper soil within it. Each root was marked by means of a numbered stake driven into the soil, so that it could be further examined after the taproot and its branches within the primary area of excavation had been studied.

There were I 5 major branches, $2-7$ inches in diameter, that had their origin on the first ${ }_{5} 5$ inches of the taproot. Seven others, varying from 2 to nearly 4 inches in thickness, arose from the taproot between $I_{5}$ and 36 inches. The depth of origin, diameter, length within the primary excavation, and diameter at the distal, severed ends are shown in table $I$.

Table I indicates the large size and widely spreading habit of the main roots. Root no. I 2 , for example, was 4.5 inches thick. It originated 8 inches below the soil surface, and ran outward a distance of I3 feet where it was still I. 2 inches thick but only 30 inches deep. All but four of the fifteen uppermost roots grew outward at so small an angle from the horizontal that they left the $\mathrm{I} 2$-foot excavation on all sides of the tree at an actual soil depth of only I 5 to 32 inches. The other four extended more obliquely downward. Among those originating deeper, five of the seven behaved like the first eleven. It must be recalled, however, that the original depth was somewhat 
greater, perhaps 16 inches, since the soil on this hillside had been eroded about this particular tree.

The root systems of two other trees, one 18 and one 14 inches in diameter, were excavated to determine whether or not the one de-
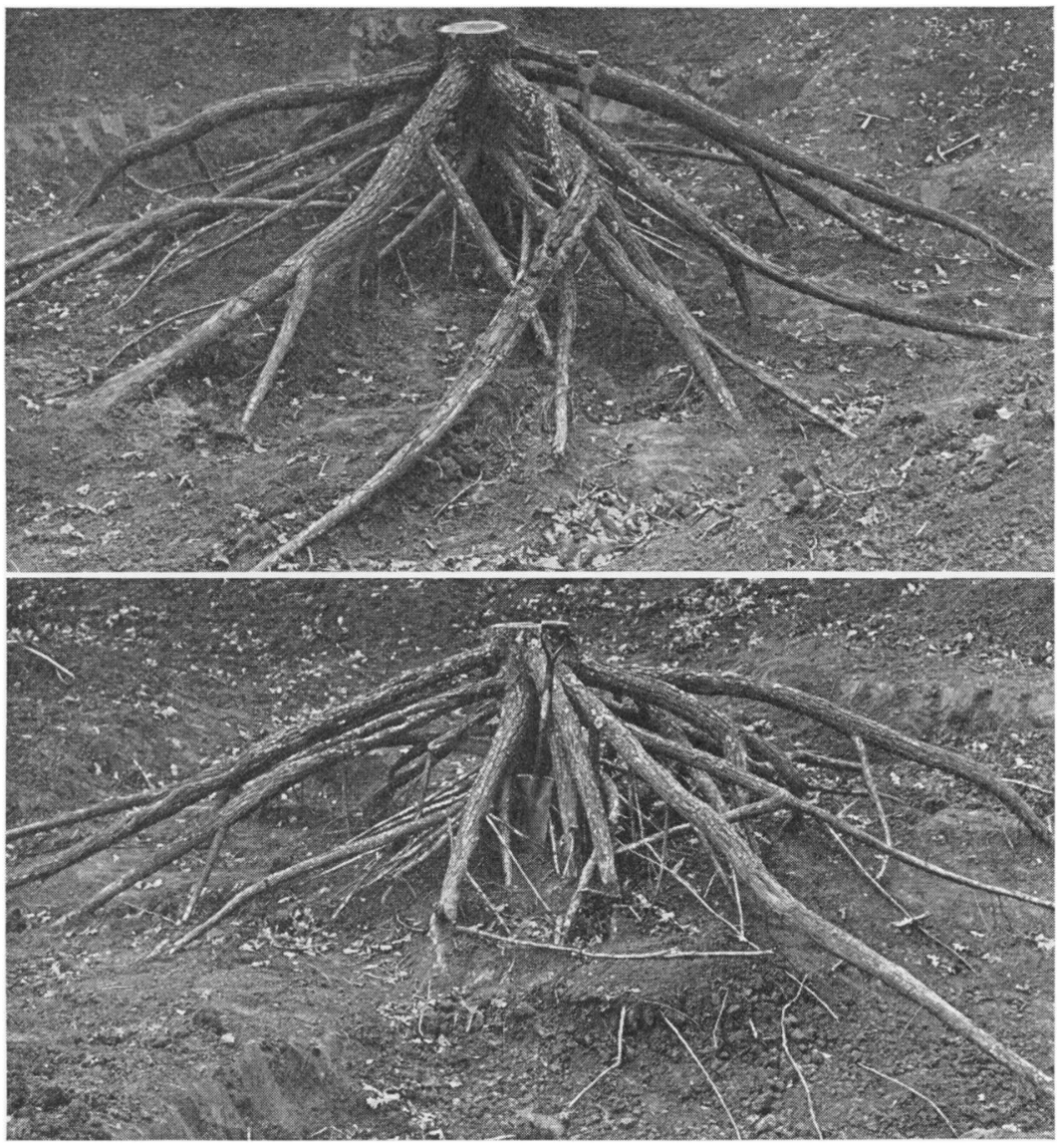

FIGS. 3, 4.-Fig. 3 (above), root system of bur oak as it appeared after removing about 2.5 feet of soil. Fig. 4 (below), same as figure 3 but from opposite side of tree.

scribed was unusually well furnished with large laterals and also to secure further information on their depth of origin, direction, and depth of growth. The data resulting from this study of the branches originating from the first 40 inches of the taproots are given in table II (cf. fig. 5). 
An examination of table II shows that the three trees had 22, 27, and 26 main roots respectively over 2 inches in diameter; nine, seven, and seven I inch thick; and that the third tree was especially well supplied with branches of smaller size. The depth of origin of the large laterals was also very similar to that of the tree previously described, although only a little erosion had occurred. The bulk of the major laterals in all cases originated in the first 2 feet of soil;

TABLE I

DATA ON MAIN LATERALS TWO OR MORE INCHES IN DIAMETER

\begin{tabular}{|c|c|c|c|c|c|}
\hline Root NUMBER & $\begin{array}{l}\text { DEPTH OF } \\
\text { ORIGIN ON } \\
\text { TAPROOT } \\
\text { (INCHES) }\end{array}$ & $\begin{array}{l}\text { Diameter } \\
\text { (INCHES) }\end{array}$ & $\begin{array}{c}\text { LENGTH } \\
\text { UNCOVERED } \\
\text { (FEET) }\end{array}$ & $\begin{array}{c}\text { DEPTH WHERE } \\
\text { CUT } \\
\text { (INCHES) }\end{array}$ & $\begin{array}{c}\text { DIAMETER } \\
\text { WHERE CUT } \\
\text { (INCHES) }\end{array}$ \\
\hline I $\ldots \ldots \ldots$ & I 5 & 3.8 & I 2.0 & 20 & 0.5 \\
\hline $2 \ldots \ldots \ldots$ & 8 & $4 \cdot 2$ & I 2.0 & I 5 & I. 2 \\
\hline $3 \ldots \ldots \ldots$ & 5 & 4. I & $5 \cdot 5$ & 20 & 2.0 \\
\hline $4 \ldots \ldots \ldots$ & I 5 & 6.2 & 6.0 & 26 & 2.0 \\
\hline $5 \ldots \ldots \ldots$ & I I & $3 \cdot 9$ & 9.0 & 26 & I. 5 \\
\hline $6 \ldots \ldots \ldots$ & 5 & 4.0 & I I .O & 24 & I.O \\
\hline $7 \ldots \ldots \ldots$ & IO & 4.8 & $\mathrm{I} 4.0$ & 30 & I.O \\
\hline $8 \ldots \ldots \ldots$ & IO & $4 \cdot 7$ & II.O & 32 & 2.0 \\
\hline $9 \ldots \ldots \ldots$ & I 4 & 6.2 & IO. 0 & $3 I$ & I. 5 \\
\hline Io.......... & I 4 & 2.0 & $6 \cdot 5$ & 30 & 0.7 \\
\hline II $\ldots \ldots \ldots$ & 8 & 6.9 & I 5.0 & 29 & I. 7 \\
\hline I $2 \ldots \ldots \ldots$ & 8 & $4 \cdot 5$ & 13.0 & 30 & I. 2 \\
\hline I $3 \ldots \ldots \ldots$ & 9 & 4.0 & $3 \cdot 4$ & 20 & $2 \cdot 5$ \\
\hline I $4 \ldots \ldots \ldots$ & I 4 & 2.7 & 12.0 & 29. & I. 5 \\
\hline I $5 \ldots \ldots \ldots$ & I 5 & 4.0 & I 2.0 & 32 & I . 2 \\
\hline I6.......... & 32 & 2.0 & I 2.5 & 24 & 0.5 \\
\hline I $7 \ldots \ldots \ldots$ & 36 & $2 \cdot 5$ & 12.0 & 30 & 0.2 \\
\hline I $8 \ldots \ldots \ldots$ & 22 & 2.2 & IO. 0 & 32 & 0.9 \\
\hline I9......... & 26 & $2 \cdot 5$ & I I.O & 38 & 0.7 \\
\hline $20 \ldots \ldots \ldots \ldots$ & 24 & 3.0 & 9.0 & 37 & I.O \\
\hline $2 I \ldots \ldots \ldots$ & 28 & 2.0 & 5.0 & 33 & I. I \\
\hline $22 \ldots \ldots \ldots$ & 25 & $3 \cdot 7$ & IO. 0 & $3 I$ & 0.7 \\
\hline
\end{tabular}

many occurred near the soil surface; and relatively few were found at depths greater than 2 feet. The characteristic direction of growth was also similar to that already described; most of the roots ran far outward, some horizontally, mostly with only a slightly downward course.

The major laterals nearly always pursued a direct course, often with long graceful curves, and with few exceptions no abrupt turns were encountered. Moreover the roots tapered gradually and, except where major branches arose, very uniformly. For example, root no. 2, with an original diameter of 4.2 inches, tapered to 3.5 
inches at 6 feet, 2.5 inches at 9 feet, and was I.2 inches thick where cut at 12 feet from its origin. No. 12 was 4.5 inches thick but had diameters of $4,3.5$, and 1.2 inches at 6,8 , and 13 feet respectively.

\section{TABLE II}

NUMBER OF MAIN LATERALS OF VARIOUS SIZES (IN INCHES) ORIGINATING ON THE FIRST 40 INCHES OF THE TAPROOTS

\begin{tabular}{|c|c|c|c|c|c|c|c|c|c|c|c|c|c|}
\hline \multirow[b]{2}{*}{ TREE } & \multicolumn{13}{|c|}{ INCHES } \\
\hline & $\begin{array}{c}\text { DI- } \\
\text { AME- } \\
\text { TER }\end{array}$ & $\begin{array}{c}0.25 \\
\text { OR } \\
\text { LESS }\end{array}$ & $\begin{array}{c}0.25^{-} \\
0.5\end{array}$ & $0.5^{-1}$ & $1-2$ & $2-3$ & $3-4$ & $4-5$ & $5^{-6}$ & $6-7$ & $7-8$ & $8-9$ & 9-10 \\
\hline $\mathbf{r} \ldots \ldots \ldots \ldots$ & I 4 & 7 & 3 & o & 9 & 7 & 4 & 8 & 0 & 3 & 0 & 0 & 0 \\
\hline$\ldots \ldots \ldots$ & I 8 & 0 & 0 & 2 & 7 & 8 & 7 & 2 & 4 & 2 & 2 & I & $\mathbf{I}$ \\
\hline $3^{*} \ldots \ldots \ldots$ & I 4 & 4 & 5 & I 6 & 7 & 8 & 8 & 9 & 0 & o & $\mathbf{I}$ & 0 & o \\
\hline
\end{tabular}

* On this tree 25 of the laterals, nearly all large ones, originated from the first 22 inches of taproot.

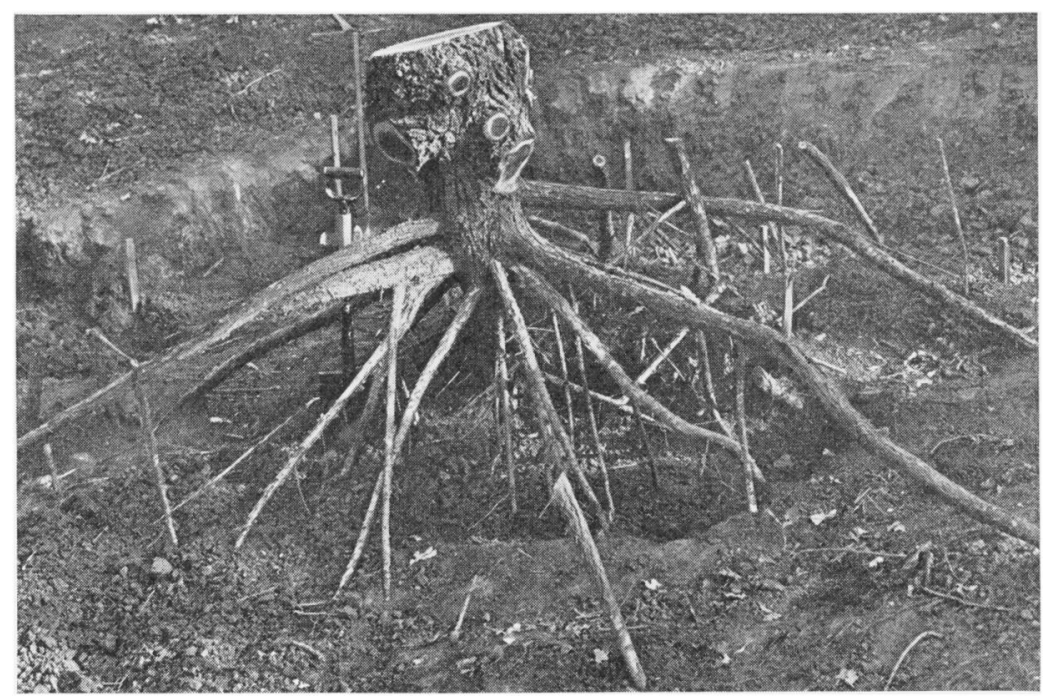

FIG. 5.-Taproot system after the large, upper lateral branches had been removed; note that the branches originating deeper take a more oblique course. Vertical roots are branches (sinkers) from the main laterals. The stakes mark places where the main branches were cut.

Grafting of roots of the primary laterals, and in fact, of roots of smaller sizes, was very much in evidence on all of the trees examined.

SECONDARY LATERALS.-The number of branches of the second order that arose from the parts of the roots thus far unearthed was 
great. Their distribution was irregular but most of the larger ones had their origin within 6 to 8 feet of the taproot. The numerous smaller ones in general arose from the more distal portions of the main roots. A total of 82 larger branches ranging in size from 0.25 to 4 inches were counted and measured. Twenty-nine belonged to the first group ( 0.25 inch), twenty-four were 0.5 inch thick; and the numbers of larger sizes, increasing in diameter by 0.5 inch respectively, were $9,7,3,5,2,2$, and $\mathrm{x}$. The direction pursued by these branches was variable. A few ran horizontally; many spread laterally, forming a $20^{\circ}-30^{\circ}$ angle with the main root and then almost paralleled its course. Others ran obliquely outward and downward. These branched similarly to the main roots, which will later be more completely described. But fully one-fifth of the branches grew so nearly vertically downward that they may be characterized as "sinkers."

The branching of the sinkers, which varied in diameter from 0.2 inch or less to 2.5 inches, was characteristic and their downward extent rather great. They were clothed with widely spreading branches, both large and small, which rebranched repeatedly, resulting in a large absorbing area. They may best be understood by a description of a few typical examples (fig. 6).

One sinker originated from a main root 18 inches from the taproot and was one of five similar branches arising at various places in the first 4 feet of its course. Its original diameter was 2 inches. It penetrated almost vertically downward, tapering gradually and rather uniformly to a depth of 7.5 feet where it was only $5 \mathrm{~mm}$. thick. Thereafter the diameter was almost uniform to a depth of $5_{5}$ feet. A large branch, 0.75 inch in diameter, arose at 12 inches from the proximal end. It ran obliquely downward at an angle of $45^{\circ}$. This branch gave rise to many laterals, for example five 0.25 inch in diameter and twelve $\mathrm{I}$ mm. thick, in the first 3 feet of its course. A lateral $5 \mathrm{~mm}$. in diameter arose 6 inches above the large one described, and another 0.7 inch thick arose at about the same level. There was a total of thirty branches in the next 5 feet. They arose at irregular intervals, and varied from I to ro $\mathrm{mm}$. in diameter. Nearly all ran outward at angles of $I 5^{\circ}$ to $45^{\circ}$ from the horizontal but a few penetrated more vertically downward. They spread widely and branched 
profusely. Two laterals, 3 and $5 \mathrm{~mm}$. thick respectively, arose at 7.5 feet depth. The larger one ran obliquely for a short distance

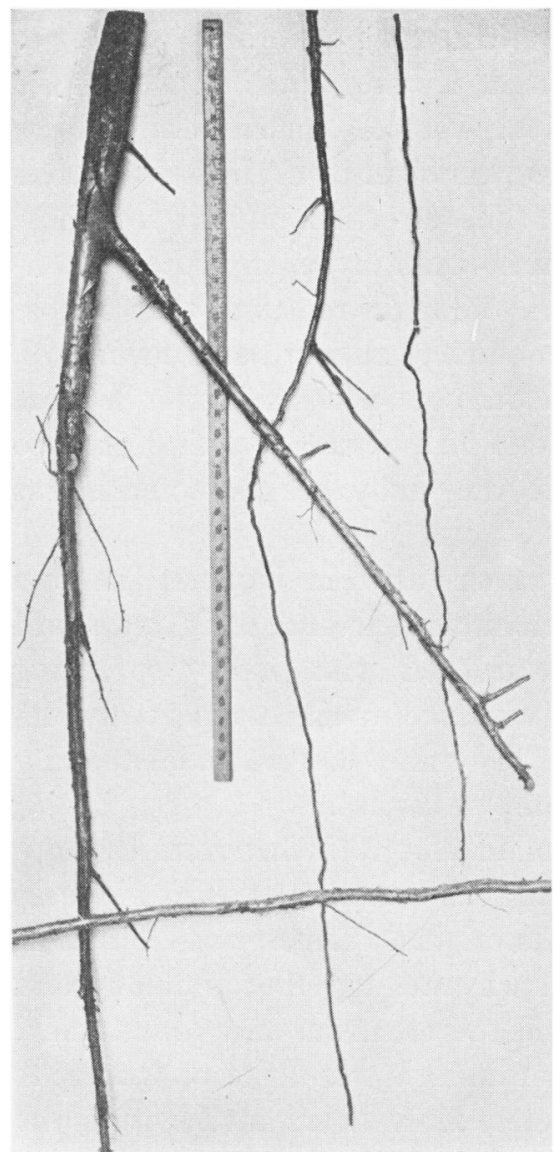

Fic. 6.- Sinker about 15 feet long in three vertical sections; note rather numerous branches. Running horizontally across the bottom is a portion of one of the numerous ropelike roots. and then turned downward and more or less paralleled the course of the main root, the size of which it approximated. Below 7.5 feet the branches were small and rather numerous but short. Only a few threadlike laterals occurred below ro feet, and just beyond a depth of $I_{5}$ feet the root ended abruptly in the hard, dry soil.

Another sinker, originating from a major lateral 4 feet from the taproot, was 2 inches in diameter. Like the preceding, it penetrated vertically downward and tapered gradually. Branches of various sizes arose in profusion. Fourteen major branches, 5 to I 5 $\mathrm{mm}$. in diameter, and an equal number of smaller ones occurred in the first 4 feet of its course. These had threadlike sublaterals in abundance, all of which were clothed with masses of absorbing rootlets. The direction of growth was similar to that already described. At greater depths the branches became more threadlike and fewer in the harder soil. Maximum penetration was about I $_{5}$ feet.

Still another sinker gave rise to seven major branches $\left(0.25^{-0.5}\right.$ inch thick) and eight smaller ones in the first foot of its course, and 
thirty-five in the next 4 feet. It then penetrated to the ro-foot level, branching more sparingly. Since several of the larger branches ran obliquely outward for distances of Io to 15 feet and all branched freely, the total soil mass penetrated by a single sinker is very great.

While a few of the sinkers examined had no large laterals and relatively few smaller ones, the preceding descriptions are typical of the group. The individual sinker develops in a manner very similar to that of a sapling oak, and if its origin were unknown it might readily be confused with a small taproot system.

TAPROOT.-The taproot was $\mathrm{I}_{4}$ inches in diameter at its origin, that is, near the old soil line and where the large lateral roots originated. But it tapered so rapidly, after giving rise to the numerous large branches, that at a depth of 3.3 feet it was only 4.5 inches thick. Its width decreased to 3.7 inches at 5 feet in depth and to I.75 inches at the 6-foot level, after giving off a branch equaling its own diameter (fig. 7). In addition to the twenty-two roots in table I, sixteen others occurred on the first 3 feet of the taproot. Ten of these were of large diameter (0.25-1.6 inches); the others were only $2-3 \mathrm{~mm}$. thick. Nearly all penetrated much more obliquely downward than the roots already described. Between the depths of 3 and 7 feet, laterals were much fewer and of smaller size; in fact there were only two with a diameter greater than 1.5 inches. Seven branches were I-I.5 inches thick; fourteen others were $0.2^{-}-\mathrm{I}$ inch in diameter; and three were of smaller size. This made a total of sixty-four primary branches from the first 7 feet of taproot, of which 60 per cent (including nearly all the larger ones) originated in the first 3 feet.

From the 6-foot level the taproot (now only 1.75 inches thick) branched sparingly and pursued a tortuous downward course. Three branches (included above) arose in the seventh foot. These were $0.75,0.5$, and 0.3 inch thick. Six other small laterals $(4-5 \mathrm{~mm}$. thick) were also found. The taproot was now reduced to a diameter of only 0.75 inch. In the eighth foot a single horizontal lateral 0.3 inch thick arose. At 9 feet in depth the main root gave rise to a small branch $4 \mathrm{~mm}$. in width which ran outward and upward. The taproot, of similar small dimension, pursued a tortuous downward course through the hard soil. Another branching reduced its size to $2.5 \mathrm{~mm}$. 
and still another to I $\mathrm{mm}$. It was now at about the ro-foot level. Only a few other threadlike branches were found at this depth. The brown, brittle, threadlike taproot and several of its branches pur-

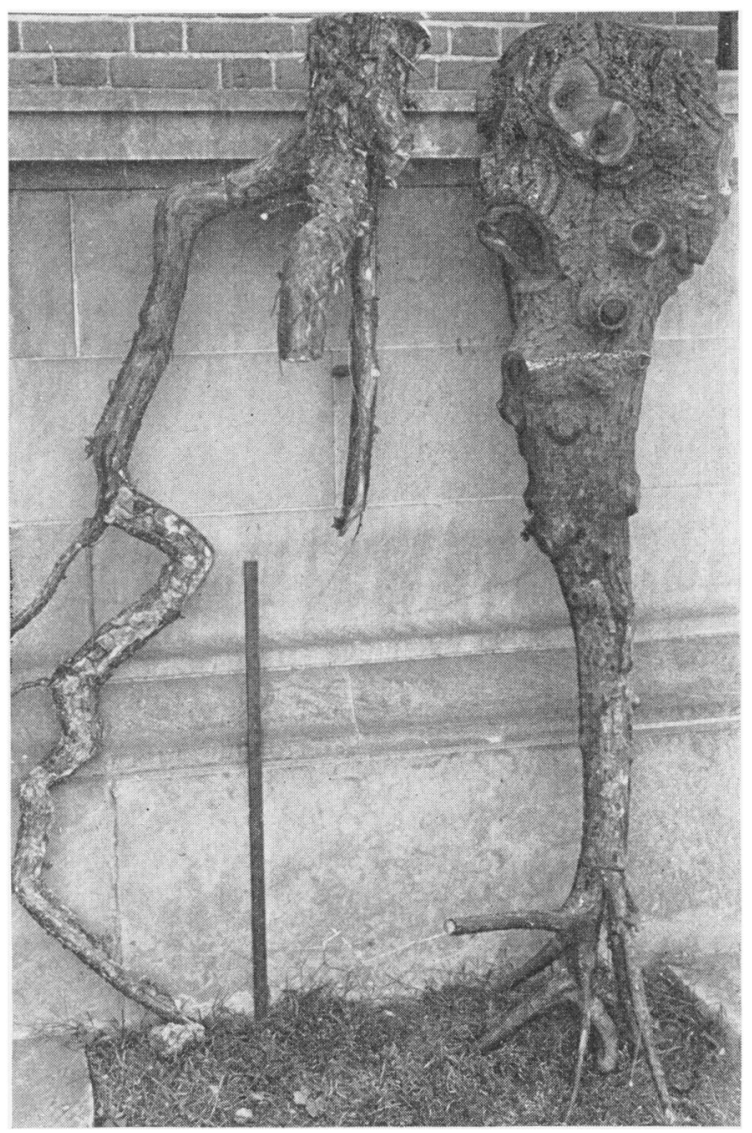

FIG. 7.-Portions of two taproots: the one on right is from tree no. I and is about 6 feet long; the other, cut at depth of the chalk line on the first, is from tree no. 3 which maintained a larger diameter (note crooked shape).

sued parallel downward courses, branching sparingly. Many of the branches were decayed near their ends and none, including the taproot, penetrated beyond $\mathrm{I} 4$ feet in depth.

The rapid tapering of the taproot and its lack of greater penetration initiated further study. Oaks no. 2 and no. 3 were felled and 
their taproots examined. That of no. 2 tapered from a diameter of I 8 to 5.5 inches in the first 3.3 feet of its course. A foot deeper it was only I.5 inches thick and at the 5.5 -foot level, 0.5 inch. Thus the taproot was again poorly developed.

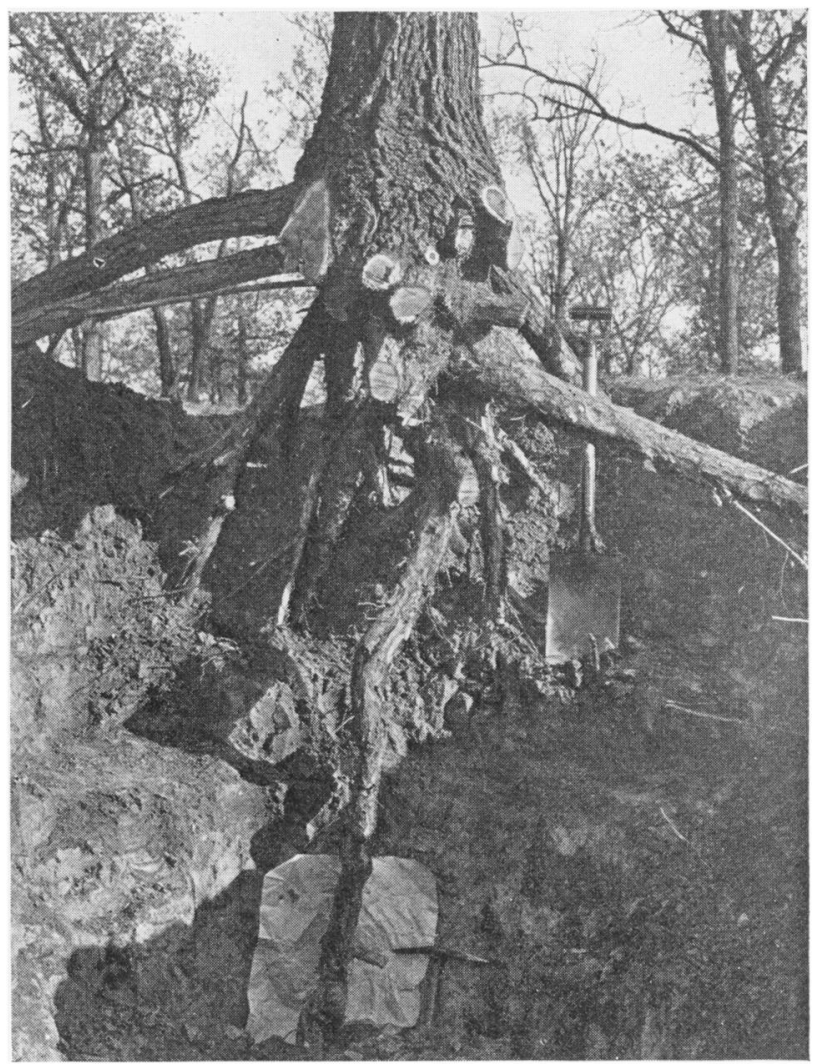

Fig. 8.-Root system of tree no. 3; taproot shown to depth of about 6 feet

On the third oak the main root lost half of its original thickness (14 inches) in the first 2 feet. At a depth of 5 feet it was only 2.7 inches thick, but at the end of the twelfth foot, the root having been much flattened and distorted for several feet, the diameters were I and 2 inches respectively (fig. 8). Here it ran horizontally for some distance, gradually narrowing and finding great difficulty in penetrating the hard soil. It probably penetrated somewhat deeper than 
the first taproot examined. It should be noted also that the portion of this taproot between the 3.3- and I 2 -foot levels was much more poorly branched than the first one described. In fact, only thirteen branches were found on this part. All but four were less than 0.5 inch in diameter.

Several other trees, where the taproots had been partly exposed by erosion, yielded similar data. A much larger specimen with a diameter of 3.3 feet was studied on a high, level terrace which the Weeping Water River had eroded. The taproot system was fully exposed for a depth of 9 feet. It was much smaller than a score of the main lateral roots and measured only 3.5 inches in diameter at 4.5 feet depth. The diameter, however, was nearly as great at the 9 -foot level.

From these studies it may be concluded that the taproot of the bur oak, at least in the type of soil where it was studied, is less extensive than many of its major branches.

ROOT DISTRIBUTION NEAR THE TREE; ROOT TYPES.-A clear description of the network of roots occupying the soil within the I 2 -foot radius of the tree is somewhat difficult. In addition to sixty-four main branches of the taproot, which occurred primarily in the first 2 to 4 feet of soil, there were eighty-two large secondary roots (0.25-4 inches in diameter). About one-fifth of these were sinkers, each often having a root system like that of a sapling oak. In addition, many roots originated from the more vertically descending main laterals which were not uncovered (and hence not included) in the earlier excavation. These, with branches, both large and small, from their secondary laterals, and also the very numerous branches of secondary roots that were originally uncovered, formed an intricate root pattern.

The area within a radius of ro feet of the tree (except close to the taproot) was especially well occupied by roots of various sizes. Aside from the large, thick roots already described, three other types predominated, and indeed intermediate sizes were relatively scarce. First there were the large ropelike roots, usually 0.5 inch or somewhat less in diameter, which ran long distances $\left(5^{-20}\right.$ or more feet) with little decrease in thickness (fig. 6). They and the larger branches, including the main laterals, gave rise to an abundance of 
tough, reddish brown, cordlike roots that were usually $3^{-5} \mathrm{~mm}$. thick, and maintained a uniform diameter for distances of 5 to more than Io feet. These ran in all directions, often even vertically upward or downward, and threaded the soil with an efficient network which, in part, was the source of the third general type, that is, the capillary branches. While these cordlike roots sometimes ran 2 feet or more with scarcely a single lateral, more usually there were five to eight branches per foot and sometimes as many as twenty to twentyfour.

These cordlike roots (and even finer branches) arose from the larger roots and, in fact, also from the main laterals. Sometimes they were sparse but often abundant. Frequently as many as twelve to twenty per foot were counted; sometimes there were several feet of main roots with none.

In general the first 6 feet of soil was filled with a well developed root system, approaching in places such a network as is often found among herbaceous plants $(\mathbf{2 6}, \mathbf{2 9})$. The root network decreased rapidly at depths of 6 to io feet, and at greater depths roots were sparse.

The smaller laterals, which undoubtedly carried on the major part of the absorption, warrant careful consideration. In fact, the description thus far has dealt with the skeletal framework from which the absorbing roots arose. This is true even where the non-absorbing roots form a tangle below ground (as was found within ro feet of the tree) similar to a thicket of branched shrubbery and small trees above the soil. Figure 9 shows a few smaller roots and the abundance of much branched rootlets.

Many of these fine rootlets, especially in the surface soil, come from obliquely or vertically ascending branches which often originate several feet in depth. For example, one root 0.4 inch in diameter was cut from a main horizontal lateral. It ran vertically upward 28 inches, gave rise to several large branches, and then turned nearly horizontally in such a manner that many of the ends of the profuse ultimate laterals came within 0.25 inch of the soil surface. Eleven branches I to $4 \mathrm{~mm}$. in diameter had their origin in the surface foot of soil. They spread widely, branched repeatedly, and their mats of ultimate rootlets almost filled the rich surface substratum. 
Many branches with absorbing rootlets were floated out in water and examined in detail. The following examples are representative of well branched roots. A section of a root 9 inches long gave rise to eight branches I mm. thick and forty-two of smaller size. The larger

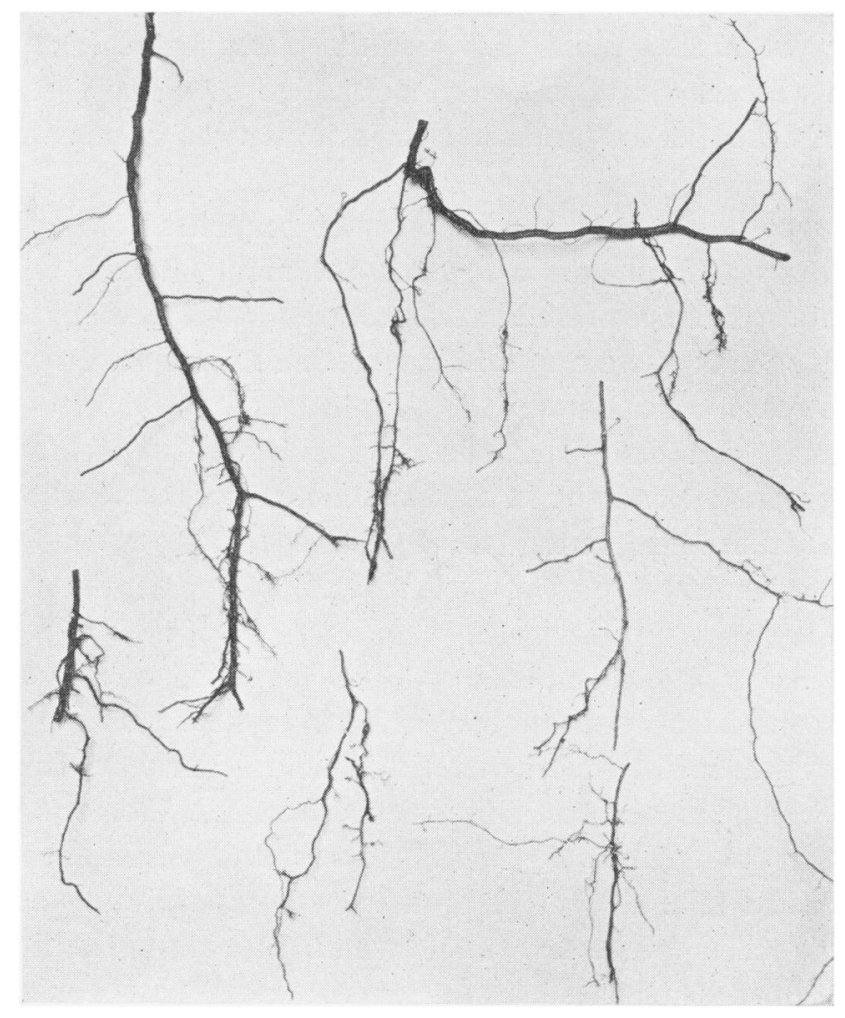

FIG. 9.-Selected fragments of roots showing usual degree of branching

ones rebranched at the rate of twelve rootlets per inch; the finer ones had seventeen to twenty-five fine laterals per unit length. Many of these were rebranched three or four times. Another root section 5 inches long had seven millimeter branches and twenty-eight threadlike ones. Branching at the rate of fourteen laterals per inch was common on fine rootlets, and five or six per inch occurred on those that were only poorly furnished with laterals. 
The root termini commonly had as many as twenty branches per inch, mostly 0.5 inch or less in length but so completely rebranched that the soil was extremely well filled. Mycorrhizal mats, yellow, white, or pink in color, were found in great abundance. Here the root mass was often flattened into one plane, forming densely appressed mats or "fans" $0.5^{-1}$ inch wide. Often fifty or more short branches per inch occurred in such areas (fig. Io). The mats were especially well developed throughout the first foot of soil but also occurred deeper. The whole horizon $A$ within a radius of $\mathrm{I} 2$ feet from the tree was well threaded with the absorbing rootlets. As the roots extended many feet farther, repeated divergence of branches continued to afford a skeletal network for the origin of more fine laterals; but here, of course, the whole territory was not so fully occupied by the roots of an individual tree.

As regards color, all of the roots whether large or small were some shade of brown,

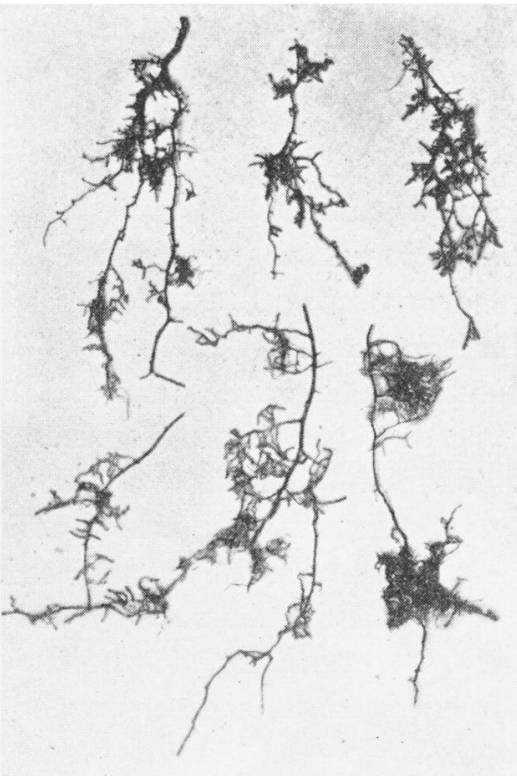

Fig. Io.-Ultimate absorbing laterals showing also some mycorrhizal "fans." varying from grayish to reddish brown. They possessed great tensile strength, being characteristically as "tough as oak."

Upon the death and decay of the roots, channels are left in the soil. One channel 0.5 inch in diameter was traced at the ro-foot level for a distance of more than 4 feet. Many smaller ones were found. Some were partially lined with fragments of old bark; others contained a new growth of roots. Undoubtedly the larger channels, at least, remain in place for long periods of time. Dead root ends are often found on vigorous forest trees, and sometimes entire roots or at least considerable portions of them may die and decay. 
EXTENT AND BRANCHING HABIT OF PRIMARY LATERALS.-As regards root extent beyond the primary excavation, the following examples are illustrative. Root no. 8 was cut i I feet from its origin where the diameter was 2 inches. Within a foot it forked dichotomously. One branch ran obliquely downward; the other ran outward almost horizontally and at a depth of about 2 feet. The latter immediately gave rise to a branch that also ran horizontally, making an angle of $25^{\circ}$ with the main root. The main root tapered to a diameter of $\mathrm{I}$ inch 3.5 feet farther out, and after giving rise to two branches each 0.25 inch thick it was only 0.5 inch in width. One of these branches ran vertically downward; the other horizontally outward. Throughout its entire course this root gave rise to many small branch roots 3 to $5 \mathrm{~mm}$. thick. These extended in all directions, as frequently upward as laterally or downward. At a distance of 30 feet from the taproot, and where the main root was only $4 \mathrm{~mm}$. thick, it turned obliquely downward. The main root now divided into numerous smaller rootlets which extended outward and downward approximately 8 feet farther.

The other main branch of no. 8 soon pursued a course more or less parallel with the surface soil at a depth between 2 and 3 feet. It also extended outward (3 I feet) before running obliquely downward. Its branching was similar to that of the other fork. The tip was only $3 \mathrm{~mm}$. in diameter and was not traced beyond 5 feet in depth.

A branch of no. 8, I inch thick, which arose at a distance of Io.8 feet from the trunk, also ran far outward. It soon branched dichotomously, one branch running downward at an angle of $20^{\circ}$ from the horizontal. The other branch was traced outward in the second and third foot of soil 23 feet farther. Here it divided into several branches only $3-5 \mathrm{~mm}$. thick. These branched again and again, running outward and downward about ro feet more. The root was ropelike and tapered so slowly that for many feet change in diameter was scarcely perceptible. Few large branches were found and smaller ones originated only intermittently. Only six laterals of various sizes arose in the first 5 feet of its course, but on other parts there were twelve to eighteen small branches per foot.

This main lateral with its widely spreading major and minor 
branches, all covered more or less profusely with absorbing rootlets, well illustrates a small part of this really wonderful anchoring and absorbing system. Sometimes a root turned upward a foot or more, or abruptly downward, but the curves were nearly always remarkably gradual and graceful compared with those of many other species of plants. The direction of growth of even isolated roots could easily be determined by their branching habit. Roots of all sizes, including the taproots and main laterals, showed a decided tendency to give rise to one or more branches where they did bend abruptly.

Often the main roots enlarged 0.5 inch or more in diameter if the soil was eroded from them or if in their course they appeared at the surface. This was due, in part, to the increase in the development of the thickness of the bark.

Further description of the lateral roots seems unnecessary; in fact, all of them were not examined. Instead, the roots of certain other oaks on gently sloping ground were studied since they were somewhat easier of access. Only two will be described.

The first was 3.6 inches thick at its origin which was 12 inches deep. It ran outward at a rather uniform depth between 2 and 2.5 feet. Thirty feet outward it was still I inch thick. It was traced Io feet farther where it was 5 feet below the soil surface. Here it turned abruptly downward, the diameter increasing to $\mathrm{I} .5$ inches. It tapered rapidly in the next 3 feet of soil but was not traced to its end. Five large branches $\left(0.25^{-0.75}\right.$ inch thick) and very numerous smaller ones arose beyond the I2-foot radius and two between 30 and 40 feet. In addition, smaller laterals were abundant.

A main lateral was examined on another tree that had a trunk diameter of $\mathrm{I} 4$ inches. It was 3 inches thick and originated at a depth of 2 feet. This root pursued a gently curving, nearly horizontal course at a depth of about 28 inches. The diameter decreased at ro-foot intervals to $2.75,2.5$, I.75, 1.25, and I.o inches respectively. At 54 feet from the tree it turned directly downward, and although this part was unearthed only a few feet, it probably penetrated deeply. Three major branches 0.5 to more than $\mathrm{I}$ inch in diameter arose in each of the three distal ro-foot sections. They ran either horizontally or obliquely upward or downward and rebranched in a manner not unlike that of the main root. Almost countless numbers 
of small rootlets originate from such a major root and its network of laterals, and the total volume of soil laid tribute by a single major branch is really enormous.

Other main branches were traced for distances of 40 to 56 feet and one to more than 60 feet. This was two to four times greater than the radius of the crown of the tree (fig. 2).

RELATIVE WEIGHT AND VOLUME OF TOPS AND ROOTS

The tree was cut at the original ground line and the top divided into convenient sections for weighing. Although the leaves were drying, few had fallen and their weight was included with that of the trunk and branches. The total weight of the top was 1285 pounds.

The large main roots from the upper portion of the taproot, except a few of the ends, were collected and weighed. The weight of the termini (which was not great) was approximated from the weight of similar roots of average length and equal diameters. All of the major roots, over $5 \mathrm{~mm}$. in diameter, from one-fourth of the area penetrated by the root system below 3 feet, were also collected and weighed and the weight quadrupled. These weights, with that of the taproot itself, gave a total which was just equal to the weight of the tops. Since the soil was dry, the wood of the roots probably contained little more water than the branches. Thus this specimen had a skeletal root system which equaled in weight that of the parts above ground. The significance of this from the standpoint of absorption is not great. It merely indicates the enormous development of the anchorage system and at the same time the extent of the framework upon which the absorbing, fibrous network of roots develops. Had all of these fine roots been collected as well, their weight would have added little to the total, but would probably have caused the weight of the roots to exceed that of the tops.

The relative volumes of roots and tops were also approximated by determining first the weight and then the volume of average samples of roots as well as tops, each of three different sizes. Since the weights of roots and tops were approximately equal, the volume of the roots, because of their greater density, was about one-tenth less than that of the wood above ground. 


\section{Discussion}

One of the most striking features of the root system of the bur oak is its wide lateral spread. BüsGen and MÜNCH (6) state: "At the margins of woods, tree roots are not seldom to be met with at a distance of 20 meters in the adjoining fields. For this reason cultivated ground near woods must be protected from the roots of trees by means of trenches."

PEREN (20) studied the roots of fruit trees in relation to spacing in the orchard as well as the length of time "filler trees" or bush fruits should be allowed to remain without seriously competing with the permanent trees. A I 5-year-old Norwegian cherry had a lateral spread of roots of 30 feet. The roots of certain varieties of $16-y e a r-$ old apple trees extended to a maximum distance of 24.3 feet from the base of the tree.

Gemmer (9) has shown that a long-leaved pine, Pinus palustris, 3 inches in diameter and 20 feet tall, had extended its roots 8 feet laterally through the sandy soil. He states that on mature trees roots 0.5 inch in diameter are not infrequently found 30 feet from the tree, a distance twice the radius of the crown.

LAITAKARI (I4) found that the longest roots of Pinus sylvestris occur on sandy heaths. The greatest lengths determined were $\mathrm{I} 7-25 \cdot 5$ meters. These findings are similar to those of AlLAN (4), who states that the roots of a matai (Podocarpus spicata) I5 meters tall, in a rain forest of New Zealand, had a lateral spread of 19.5 meters from the base of the tree.

There is considerable evidence that the roots of trees developing in poorer, lighter, well aerated soils tend to grow longer and often thinner and straighter than those in more compact and richer soils which are shorter and often thicker, pursuing a more devious course. Since the bur oak grew in fertile, compact, but well aerated silt loam soil, its great lateral extent cannot be attributed to these factors of the substratum. It would seem that the scarcity of the water supply, at least during recurrent periods of drought, is the chief external factor promoting extensive root development. This has repeatedly been determined experimentally for various herbaceous plants, and also undoubtedly holds for trees (I3). 
LAITAKARI (14) finds that the size of the tree and the length of the root system are rather closely dependent upon each other. It thus seems clear that the small size of the trees of these marginal oak forests is limited by the ability of the root system to furnish sufficient water for greater growth. An open stand where the crowns do not touch is indeed a closed one so far as the overlapping root systems and the supply of the dominant limiting factor, water, are concerned.

The more or less vertical growth of roots from the deeper, large horizontal or oblique branches is a rather common phenomenon among trees. For example, it has been found in Europe (Hilf II) that the roots of the beech do not extend beyond the crown but run downward more or less diagonally to various depths. Branches from these deep roots extend upward to the humus layer, where they rebranch profusely in the richer surface layers of soil. In fact, HiLF states that notwithstanding the deep skeletal root system, the beech is especially dependent upon the humus layer for its nutrients. PELHAM (19) found that the large primary laterals of the pecan extended widely at depths between 2 and 5 feet. They gave rise to an abundance of vertical "feeding roots" 0.25 inch or less in thickness which extended nearly to the surface of the soil.

The intergrowth of roots is a common phenomenon in many forest trees. It is found most abundantly within a few feet from the base of the tree. Both horizontal and vertical roots are concerned; in fact the two types were frequently grafted one into the other. LAITAKARI (I4) states that in the Scotch pine, roots are frequently found which only connect two other roots and do not grow any farther. $\mathrm{He}$ suggests that the main purpose of this kind of "bridge-root" seems to be to strengthen the root system. None of these were seen in the oak.

The phenomenon of root intergrowth is easily understood when the very firm structure of the soil is considered. The soils of horizons $B$ and $C$ were both very hard and difficult to remove, even with a hand-pick. The extreme compactness of the soil about the roots, increasing with root diameter, although not surprising is remarkable. As a result of growth, the taproot and its large branches compressed the soil about them so greatly that it was removed only with much 
difficulty. Two young roots coming into contact would exert in their enlargement an enormous pressure, not only against the soil but also against each other. Under such conditions grafting would be almost an inevitable result.

One very noticeable phenomenon observed in the excavation was the small effect a first or second generation of trees had upon the prairie soil. In the columnar layer there was, as in the case of herbaceous plants of the prairie, a marked tendency of the roots to follow the cleavage planes between the columns and form a network of absorbing rootlets which spread out over their surfaces. BURGER (5) has shown the important part played by the roots of trees in preparing suitable soil for forest growth. Numerous investigators have found that the roots of trees frequently grow along channels of decaying or decayed roots of former generations. Here they meet little mechanical resistance, have an abundant supply of air, usually also plenty of water, and immediate access to the nutrients as rapidly as they are liberated in the process of decay. In some cases they seem to be of importance in directing the roots to the ground water. Coniferous roots develop especially well where the roots of hardwoods have made deep root channels.

That the adaptation of a species to its habitat is largely a matter of root development is a viewpoint that is being strongly supported by rapidly accumulating evidence. Open stands in forests are caused, not so much by intolerance to shade perhaps as by competition of widely spreading roots. AALtonen (I) has reached the conclusion "that the space arrangement of those parts of the trees which are above the soil is mainly decided by their roots and the competition existing between them for the water and food in the ground." Other investigators have been led to a similar conclusion. BüSGEN and MÜNCH (6) point out that the number, direction, and size of root branches express first of all adaptations to the environment, and that broad-crowned, deeply branched, isolated trees have therefore much larger masses of roots than those confined in dense woods. ADAms (2) has shown that close spacing results in a marked change in the root form of jack pine, modifying its widely spreading root system into a vertical form with much branched, short, stubby roots.

The severest competition between individual trees takes place in 
pure stands, such as the bur oak, since the roots tend not only to occupy the same layers of soil but to develop at about the same time. In mixed stands such as pine, birch, and spruce, competition among the roots has been shown to be much less severe than in an equally dense stand of a single species. This is due to the fact that the horizontal roots of these species occupy the soil at different levels. Thus in Europe an undergrowth of birch often thrives under spruce (15). Some interesting cases have been found where one species of tree has actually destroyed another by root competition, although the crowns did not touch. Populus canadensis has thus been replaced by Elaeagnus angustifolia and Maclura aurantiaca by Ulmus campestris ( $\mathbf{1 7}$ ).

From these data we may conclude that the small size, usually wide spacing, and very extensive root system of the bur oak are adaptations to a relatively dry soil and atmospheric conditions scarcely congenial to tree growth. Its successful competition against the grasses and shrubs is made possible by the rapid growth and deep penetration of the young root system and by its widely spreading habit which enormously increases the soil volume from which water may be secured to meet the needs of the growing top.

\section{Summary}

I. An ecotone between the grassland and the deciduous forest along the Missouri River occurs in southeastern Nebraska. The mean annual precipitation is $28-32$ inches; humidity is relatively low, evaporation and wind movement are relatively high; the silt loam soils are deep but during drought contain only a small amount of water available for growth. Thus competition for water between the grasses and the invading shrubs and trees is great.

2. Quercus macrocarpa is the most xeric forest tree. Since the cessation of prairie fires it is invading the grassland either directly or in the wake of the Rhus-Symphoricarpos-Corylus chaparral.

3. The shrubs advance largely by means of rhizomes into the grassland. Their roots often extend outward and then upward under the grasses. Those of Symphoricarpos especially are so finely branched and abundant as to compete successfully with the excellently developed and extensive root systems of the plants of the prairie. 
4. The oak seedling develops a deep taproot before the leaves are unfolded. The strong, finely branched taproot extends into moist soil $3-5$ feet the first summer.

5. Mature trees 50-65 years old were $35^{-40}$ feet tall. I 2-I 8 inches in basal diameter, and grew ro-40 feet apart in a pure stand.

6. The taproot gave rise to thirty or more large main branches, most of which arose in the first 2 feet of soil. It tapered rapidly and extended to a depth of $\mathrm{I} 4$ feet.

7. Most of the main branches, which varied from $I$ to 7 inches in diameter, extended widely (20-6o feet) before turning downward. Some grew even deeper than the taproot. All branched repeatedly, and together they occupied a very large volume of soil.

8. Many branches of the main roots grew vertically downward 8-I 5 feet, each more or less resembling the taproot system of an oak sapling. Others extended obliquely or vertically upward and filled the surface soil with a mat of absorbing rootlets.

9. Ropelike roots, 0.5 inch or less in diameter, extended many feet without much change in thickness. A cordlike type, 3-5 $\mathrm{mm}$. thick, was also abundant. A third type consisting of fine, much branched rootlets clothed the widely extending skeletal framework and furnished the bulk of the absorbing surface. Mycorrhizal mats were abundant.

Io. The weight of the roots equaled that of the tops; the volume of the roots was about one-tenth less than that of the parts above ground.

I I. Low water content of soil is compensated by a widely spreading, well branched root system. This may account for the wide spacing of the oak trees and the open forest canopy.

UNIVERSITY OF NEBRASKA

LiNCOLN, NeB.

[Accepted for publication February I6, I932]

\section{LITERATURE CITED}

I. Aaltonen, V. T., On the space arrangement of trees and root competition. Jour. Forestry 24:627-644. I926.

2. Adams, W. R., Effect of spacing in a jack pine plantation. Vt. Agric. Exp. Sta. Bull. 282. I928. 
3. Aikman, J. M., Distribution and structure of the forests of eastern Nebraska. Univ. Nebr. Studies 26: I-75. I929.

4. Allan, H. H., The surface roots of an individual matai. New Zealand Jour. Sci. and Tech. 8:233-234. I926.

5. Burger, H., Physikalische Eigenschaften der Wald- und Freilandböden. Mitteilungen der Schweizerischen Centralanstalt f. d. forstliche Versuchswesen, Bd. I3. Heft I. (cited by Laitakari, I927). I922.

6. BüSGEN, M., and MÜNCH, E., The structure and life of forest trees. pp. 269300. 1929.

7. Cannon, W. A., Treelessness in prairie regions. Carnegie Inst. Wash. Yearbook I2:7I-72. I9I3.

8. Clements, F. E., Weaver, J. E., and Hanson, H. E., Plant competition. Carnegie Inst. Wash. Publ. 398. I89-20I; I 54-I70. I929.

9. Gemmer, E. W., The root system of a longleaf pine. Scientific Monthly 27:384. I928.

ro. GURSky, A. V., The root systems of Fraxinus excelsior L., F. pennsylvanica Marsch., and Acer negundo L., on the black soils of Kuban. Bull. App. Bot. Gen. and Plant-Breed. 21: I45-I84. I929.

Ir. Hilf, H. H., Wurzelstudien an Waldbäumen. Die Wurzelausbreitung und ihre waldbauliche Bedeutung. I927.

12. Holch, A. E., Development of roots and shoots of certain deciduous tree seedlings in different forest sites. Ecology I2:259-298. I93 I.

I3. JEAN, F. C., and Weaver, J. E., Root behavior and crop yield under irrigation. Carnegie Inst. Wash. Publ. 357. I924.

I4. Laitakari, E., Männyn juuristo, morfologinen tutkimus. Acta Forestalia Fennica 33: I-380. I927.

I5. - Die Wurzelforschung in ihrer Beziehung zur praktischen Forstwirtschaft. Acta Forestalia Fennica 33: I-21. I929.

I6. Luncz, G., Recent research work on the root systems of forest trees. Monthly Bull. Agric. Sci. and Prac. 22:239-243. I93I.

I7. MAGYAR, P. Gyökérvizsgálatok csemetekerti és szikes talajban. Erdészeti Kisérletek I929: I 17-I65. I929.

18. Partridge, N. L., and Veatch, J. O., The relationship between soil profile and root development of fruit trees. Mich. Agric. Exp. Sta. Quart. Bull. 14. 200-207. 1932.

19. Pelham, J. L., Pecan root observations and their relation to cultural practice. Nat. Pecan Growers' Assoc. Bull. 2. I30-I35. 1928.

20. Peren, G. S., Data on the lateral spread of the roots of fruit trees. Jour. Pom. and Hort. Sci. 3:96-IO2. I923.

2I. Rogers, W. S., and Vyvyan, M. C., The root systems of some ten year old apple trees on two different rootstocks, and their relation to tree performance. Ann. Rep. East Malling Res. Sta. 14-15:31-43. I928.

22. Stevens, C. L., Root growth of white pine. Yale Univ. Sch. Forestry Bull. 32. I93I. 
23. Toumey, J. W., Initial root habit in American trees and its bearing on regeneration. Inter. Cong. Plant Sci. I:713-728. I929.

24. Watt, A. S., Preliminary observations on Scottish beechwoods. Jour. Ecol. I9:32I-359. I93I.

25. Weaver, J. E., The ecological relations of roots. Carnegie Inst. Wash. Publ. 286. 25-30. I9I9.

26. —— - Root development of field crops. McGraw-Hill Book Co. New York. 1926.

27. - Who's who among the prairie grasses. Ecology I2:623-632. I93 I.

28. — - and CRIST, J. W., Direct measurement of water loss from vegetation without disturbing the normal structure of the soil. Ecology 5: I53-170. I924.

29. - , and BRUner, W. E., Root development of vegetable crops. McGraw-Hill Book Co. New York. I927.

30. - - and Himmel, W. J., The environment of the prairie. Conserv. Dept., Conserv. and Surv. Div., Univ. Nebr. Bull. 5. I-50. I93I.

3i. Weaver, J. E., and Fitzpatrick, T. J., Ecology and relative importance of the dominants of tall-grass prairie. Bot. GAZ. 93:II3-I50. I932. 